\title{
Pragmatic framework of programme organizational capability for delivering megaprojects at design and construction phases: a Chinese client perspective
}

\author{
YI HU ${ }^{1 *}$, ALBERT P. C. CHAN ${ }^{1}$ and YUN LE ${ }^{2}$ \\ ${ }^{1}$ Department of Building and Real Estate, The Hong Kong Polytechnic University, Hung Hom, Kowloon, Hong Kong, \\ People's Republic of China \\ ${ }^{2}$ Department of Construction Management and Real Estate, School of Economics and Management, Tongji University, \\ Shanghai, People's Republic of China
}

(Received 17 December 2014; accepted 30 January 2015)

\begin{abstract}
The number of construction megaprojects, with costs exceeding RMB50 billion (nearly USD800 million), has increased exponentially in China in the past two decades because of outstanding economic achievements and fast urbanization. However, these projects are usually beset with underperformance problems, such as cost overruns, safety incidents, functional and quality defects, and poor environmental and sustainable performance. Programme management has been increasingly advocated as a pragmatic approach through the centralized coordinated management to improve megaproject performance at the overall organizational level. This paper reports a pragmatic framework of programme organizational capability comprising 24 factors based on a case study of the Shanghai Expo construction. The 24 programme organizational factors (POFs) identified from the literature review and interviews are grouped into three categories in terms of organizational capability theory, organizational contextual capability, organizational core capacity and organizational motivational capability. They represent three kinds of organizational capabilities for the success of construction megaprojects in China from the client's perspective. In addition, archival evidence related to the operation of the 24 POFs in the case study was further examined, which confirmed the usefulness and validity of the developed framework in this study. Findings of this study provide an overall picture for scholars and practitioners to appreciate key issues of programme organization in managing megaprojects.
\end{abstract}

Keywords: China, clients, construction megaprojects, programme organizational capability.

\section{Introduction}

The number of construction megaprojects has increased exponentially in China in the last two decades because of the outstanding economic achievement and rapid urbanization. A recent investigation conducted by the Tongji University (Le, 2009) revealed that 203 construction megaprojects costing over RMB50 billion (nearly USD800 million) were initiated from 1990 to 2009 . However, these projects are usually beset with underperformance problems, such as cost overruns, safety incidents, functional and quality defects and environmental pollutions (Xue et al., 2008; Le, 2009). Flyvbjerg et al. (2003) stated that low performance is a common problem for construction megaprojects worldwide. The root cause of these problems is that a construction megaproject is usually divided into several units and executed in a dispersed manner, and the temporary client organization established by the client to manage the megaproject lacks the necessary capability to coordinate and control the dispensed execution of the delegated constituent projects within the megaproject at the overall level. To deal with this challenge, programme management has been increasingly advocated as a pragmatic means of improving megaproject performance through the coordinated management of constituent projects within a megaproject in the last

*Author for correspondence. Current Address: Department of Construction Management and Real Estate, School of Economics and Management, Tongji University, Shanghai, People's Republic of China. E-mail: huyi82@hotmail.com 
decade (Rasdorf et al., 2010; Beehler, 2009; Eweje et al., 2012). Pellegrinelli et al., (2011) stated that programme management enables organizational development for improved performance (Lehtonen and Martinsuo, 2008).

In a recently completed megaproject - the Shanghai Expo construction-the client utilized the programme management approach in constructing an effective programme organization, thus completing the megaproject ahead of schedule and attaining prescribed delivery objectives in safety, quality and environment within the approved budget (Bureau of Shanghai Expo Coordination (BSEC) and Shanghai Commission of Urban and Rural Construction and Transportation (SCURCT), 2010). As one of the most prominent construction megaprojects in China, the Shanghai Expo includes 136 pavilions and over 160 supporting facility buildings with a total floor area of 2.3 million $\mathrm{m}^{2}$; all the construction works of these buildings and infrastructures within the Expo site were divided into 10 constituent projects to complete the construction on time. The client faced multiple managerial challenges in delivering this megaproject within a short deadline of nearly 45 months. These challenges include working on a mega construction scale, employing hundreds of contractors and designers, and coordinating a significant amount of tasks as a result of adopting a design—bid—build mode. Each project was executed by a different project management team (PMT) of the client organization. To deal with these challenges, the client utilized the programme management approach with the assistance from a research team from Tongji University and established a programme organization consisting of a programme governance board, a programme management office (PMO) and 10 functional management divisions (FMDs) to coordinate and integrate the execution of the tasks performed by the 10 PMTs (Figure 1).

The research question of this study was derived from the client's successful experience of applying the programme management approach. With the assistance of the research team, the client established a programme organization and successfully delivered the project within the extremely compressed schedule and approved budget. The client affirmed that applying programme management approach was the key to sustaining the delivery success of Shanghai Expo construction at the organizational level (BSEC and SCURCT, 2010). This action research project also received the 2010 Project Excellence Prize from the International Project Management Association (IPMA, 2014). Two of the authors served as Director/Associate Directors in the consulting project and involved the entire process of developing a programme organization and maintaining its effectiveness for the successful delivery of Shanghai Expo construction. Drawing upon this successful experience, further research was conducted in this study to develop a pragmatic and integrated framework of programme organizational capability for the delivery success of construction megaprojects in China based on a case study of Shanghai Expo construction. Pellegrinelli et al. (2011) defined programme management as 'a framework to coordinate, communicate, align, manage, and control activities to achieve a desired synergy, benefits, outcome, or vision'. Specifically, the aim of the current work is to identify the factors of a client's programme organization established to deliver its megaproject and then formulate a pragmatic and integrated framework of programme organizational capability by categorizing these emerging factors.

\section{Developing programme organizational capabilities for the success of construction megaprojects}

Growing research efforts have been devoted to megaproject research in the past decade as a result of rapid developments of construction megaproject practice worldwide ( $\mathrm{Hu}$ et al., 2013). The term megaproject is a social construct that refers to large and complicated construction projects in the real world such as skyscrapers, dams, bridges and railways. However, managing these megaprojects not only faces increasing internal complexities as a result of large size, dispensed executions, long construction span, high technical complexity and numerous participants' involvement in the megaprojects, but also the external complexities caused by contextual uncertainty, such as widespread economic fluctuation ( $\mathrm{Hu}$ et al., 2013). In a research perspective, a megaproject can be conceptualized as a programme that 'consists of a set of related projects required organizational changes to reach a strategic goal and to achieve the defined business benefits' (IPMA, 2006). This perspective has been increasingly advocated by scholars in the past few years (Artto et al., 2008a; Kim et al., 2009; Pellegrinelli et al., 2011; Eweje et al., 2012). Morris (2013) stated that project size or complexity can be managed by dividing a project into several constituent projects and simplifying them. In practice, a megaproject is executed as a group of several constituent projects while sharing common objectives, thus megaproject management is a matter of programme management. Remington and Pollack (2008) emphasized that programme management is a means of 


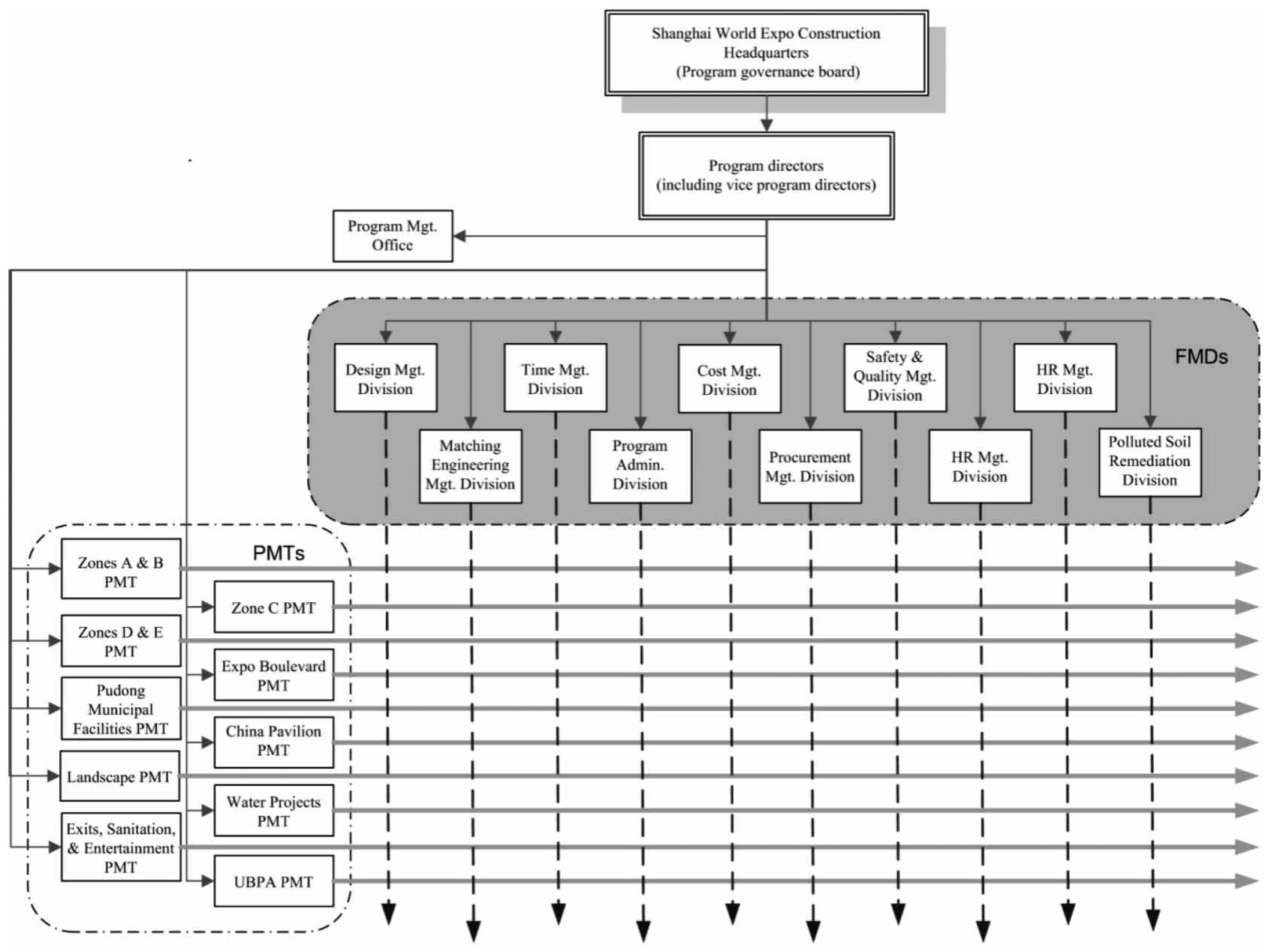

Figure 1 The client organization of the Shanghai Expo Construction (Source: SECH Office, 2008). Notes: Mgt.-Management and Admin.-Administration

dealing with all kinds of internal and external project complexities, such as structural, technical, directional and temporal. Although programme management stems from project management (Morris, 2011), Pellegrinelli et al. (2011) stated that the core of programme management is to address capabilitybuilding issues in various organizational circumstances. Pellegrinelli (2002) also proposed a nineaspect competency framework for programme success. Partington et al. (2005) developed a 17-attribute framework of programme management work by conducting case studies of 15 projects. Rasdorf et al. (2010) stated that, despite increasing recognition of the role of programme management in construction, existing research lacks concerns on the construction industry background. In construction megaprojects, temporary clients established by the government face great challenges of managing project complexity and achieving prescribed objectives. Similar to permanent organizations such as firms (Dosi et al., 2000), temporary client organizations also need to develop and maintain capabilities to execute megaproject construction and accomplish prescribed objectives. Therefore, this study aims to develop a programme organizational capability framework in the clients' viewpoint.

\section{Research methodology}

Drawing upon the successful experience of implementing the programme management approach in the case project, a further research study was conducted with a mixed-style methodology employed after the Shanghai Expo construction. First, an extensive literature review was conducted in nine peer-reviewed journals to identify programme organizational factors (POFs). The POFs are regulative, normative, technical and cultural-cognitive elements at multiple levels of programme organization within which the client utilizes a 
programme management approach for megaproject success, such as organizational units, rules and processes, managerial technology and tools. The aim of literature review was to make empirical data obtained from the case study better ground on the theoretical foundation. Second, the identified POFs were verified and elaborated by semi-structured interviews with five selected experts involved in the case study, which resulted in two additional POFs added. Haigh (2008) noted that interviews are useful in extracting the knowledge behind a participant's experience, such as POFs. Third, the case study and archival methods were both triangulated to verify all resulting POFs. Morris and Hough (1987) stated that the case study can be used in investigating megaproject-related topics as it helps researchers to understand and appreciate various factors that specifically influence megaprojects, such as organizational, managerial, political and other dynamics. The archival method was useful in tracing organization, processes, and interpretations and actions of these elements (Ventresca and Mohr, 2005). Combining these two methods could examine the usefulness of the identified POFs and assure the validity of the developed framework consisting of these POFs.

\section{Identifying the POFs by the literature review}

The review scope includes 37 relevant papers published in nine peer-reviewed construction management journals between 2000 and 2010. The nine journals include the International Fournal of Project Management, Project Management Fournal, Leadership and Management in Engineering, Fournal of Construction Engineering and Management, Fournal of Asian Architecture and Building Engineering, Construction Management and Economics, Engineering, Construction and Architectural Management, Fournal of Management in Engineering and Proceedings of Institution of Civil Engineers-Civil Engineering. These nine journals were identified as sources with the most papers on the relevant topics identified by search engines of the Scopus and the Web of Science according to the method advocated by Ke et al. (2009). The review scope also includes 87 megaproject papers identified from the same sources (journals) published in the same period as mentioned ( $\mathrm{Hu}$ et al., 2013). These papers were included because research on programme management is rooted in megaproject practices (Artto et al., 2008a). All literature research work was completed in February 2011. Only the POFs identified from the 87 megaproject papers that were consistent with the programme management literature were deemed appropriate for incorporation into the conceptual model of programme organizational capability. With the recognition that there may exist a gap between the journal literature and practical knowledge and experience, POFs were identified according to two criteria. First, the identified POFs should be consistent with the evidence on the Shanghai Expo construction. Second, the items defining each POF should be clearly and easily understandable to industry professionals. The selection of criteria was based on author's involvement in the Shanghai Expo construction for almost three years. Finally, 22 POFs were identified as given in Table 1 .

\section{Verifying and elaborating the identified POFs by the interviews}

Semi-structured interviews with five former senior executives in the client organization of the Shanghai Expo construction were conducted to identify POFs. The client of the Shanghai Expo constructed an integrated programme organization by hiring a programme management consultant (BSEC and SCURCT, 2010). Five former senior executives served in the client's programme organization of the case were invited and agreed to attend the interviews. As given in Table 2, five experts satisfied the following selection criteria were interviewed: (1) at least-10-year construction management experience, (2) hands-on experience in the megaproject case and (3) sound knowledge and understanding of the case's client organization. All the experts have different specialties and involved in the PMO and FMDs at the programme level.

Each interview typically lasted for an hour, and dialogues were transcribed into written reports after the interview. The accuracy of the reports was verified by the corresponding interviewees prior to subsequent analysis. Qualitative interview data acquired from the interviews were coded by the constant comparative method using the qualitative data analysis software NVivo 9.2 (King, 2008). The interviews identified 20 POFs; 18 of them were the same as identified from the literature representing $82 \%$ of commonality. Two additional POFs, namely procurement management and technology management, were added in the identified 22 POFs to refine the model. All the interviews were conducted in January 2012.

\section{Case study}

The International Development Research Center (IDRC) and the Inter-American Development Bank (IADB) (2002) provided a three-aspect framework of assessing development project organizations in developing countries. The framework categorized project organizational factors into three groups: environment, capacity and motivation. Correspondingly, a 
Table 1 Categories of POFs by previous studies

\begin{tabular}{|c|c|c|c|c|c|c|c|c|c|c|c|c|c|c|c|c|c|c|c|c|c|c|}
\hline \multirow[b]{2}{*}{ Previous Studies } & \multicolumn{2}{|c|}{$\begin{array}{c}\text { Environmental } \\
\text { capability }\end{array}$} & \multicolumn{16}{|c|}{ Core capacity } & \multicolumn{4}{|c|}{ Motivational capability } \\
\hline & 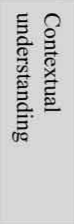 & 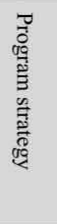 & 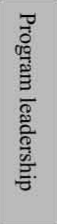 & 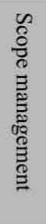 & 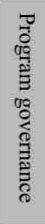 & 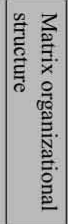 & 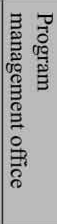 & 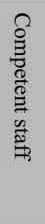 & 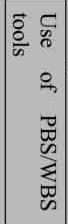 & 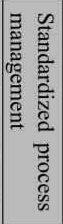 & 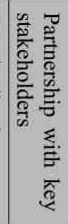 & 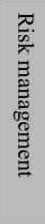 & 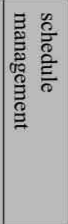 & 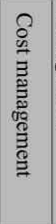 & 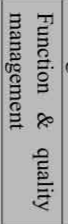 & 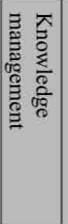 & $\stackrel{\check{n}}{\mathrm{n}}$ & 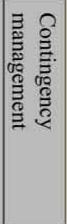 & 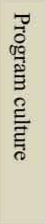 & 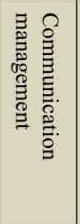 & 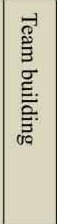 & 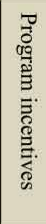 \\
\hline Artto et al. (2008a) & & & & & $\sqrt{ }$ & & $\sqrt{ }$ & & & & & & & & & & & & & & & \\
\hline Brady \& Davies (2010) & & & & & & & & & & & & & & & & & & $\sqrt{ }$ & & & & \\
\hline Buuren et al. (2010) & & & $\sqrt{ }$ & & $\sqrt{ }$ & & & & & & $\sqrt{ }$ & & & & & & & & & & & \\
\hline Crawford \& Nahmias (2010) & & & $\sqrt{ }$ & $\sqrt{ }$ & $\sqrt{ }$ & & & & & $\sqrt{ }$ & $\sqrt{ }$ & $\sqrt{ }$ & & $\sqrt{ }$ & $\sqrt{ }$ & & & & $\sqrt{ }$ & $\sqrt{ }$ & $\sqrt{ }$ & \\
\hline Davies et al. (2009) & & & & & & & & & & $\sqrt{ }$ & & & & & & & & $\sqrt{ }$ & & & & \\
\hline Dvir \& Shenhar (2011) & & & $\sqrt{ }$ & $\sqrt{ }$ & & & & & & & $\sqrt{ }$ & & & & & $\sqrt{ }$ & & & $\sqrt{ }$ & & & \\
\hline Gray (2001) & $\sqrt{ }$ & & & & & & & & & & & & & & & & & & & & & \\
\hline Geraldi et al. (2010) & & & & & & & & $\sqrt{ }$ & & & & & & & & & & $\sqrt{ }$ & & & & \\
\hline Greiman (2010) & & & & & & & & & & & $\sqrt{ }$ & & & & & & & & & & & \\
\hline Kim et al. (2009) & & & & $\sqrt{ }$ & & & & & & & & & & & & & $\sqrt{ }$ & & & & & \\
\hline Ko \& Paek (2008) & & & & & & $\sqrt{ }$ & $\sqrt{1}$ & & & $\sqrt{ }$ & & & & & & & & & & & $\sqrt{ }$ & \\
\hline Kumar \& Hsiao (2007) & & & $\sqrt{ }$ & & & & & & & & & & & & & & & & & & & \\
\hline $\begin{array}{l}\begin{array}{l}\text { Lehtonen } \\
(2008)\end{array} \\
\end{array}$ & & & & & $\sqrt{ }$ & & & & & & & & & & & & & & & & & \\
\hline Lycett et al. (2004) & & & & $\sqrt{ }$ & $\sqrt{ }$ & $\sqrt{ }$ & & & & & & & $\sqrt{ }$ & & & $\sqrt{ }$ & & & $\sqrt{1}$ & $\sqrt{ }$ & & \\
\hline Maylor et al. (2006) & & $\sqrt{ }$ & & $\sqrt{ }$ & $\sqrt{ }$ & & & & & $\sqrt{ }$ & & & & & & & & & & $\sqrt{ }$ & & \\
\hline Modig (2007) & & & & & & $\sqrt{ }$ & & & & & & & & & & & & & & & & \\
\hline Molenaar (2005) & & & & & & & & & & & & $\sqrt{ }$ & & $\sqrt{ }$ & & & & & & & & \\
\hline Nguyen et al. (2004) & & & $\sqrt{ }$ & $\sqrt{ }$ & $\sqrt{ }$ & & & $\sqrt{ }$ & & & & & & $\sqrt{ }$ & & $\sqrt{ }$ & $\sqrt{ }$ & & & $\sqrt{ }$ & & $\sqrt{ }$ \\
\hline Nieminen \& Lehtonen (2008) & & & & & $\sqrt{ }$ & & & & & $\sqrt{ }$ & & & & & & & & & & & & \\
\hline O'Laery \& Williams (2008) & & & & & & & & & & & & & & & & & $\sqrt{ }$ & & & & & \\
\hline $\begin{array}{l}\text { Office of Government } \\
\text { Commerce (OGC) (2003) }\end{array}$ & & & & $\sqrt{ }$ & & & & & & & $\sqrt{ }$ & $\sqrt{ }$ & & & $\sqrt{ }$ & & $\checkmark$ & $\checkmark$ & & & & \\
\hline Partington et al. (2005) & $\sqrt{ }$ & & & $\sqrt{ }$ & $\sqrt{ }$ & $\sqrt{ }$ & & & & & & $\sqrt{ }$ & $\sqrt{ }$ & $\sqrt{ }$ & & & & & & & & \\
\hline $\begin{array}{l}\text { Pellegrinelli/ Pellegrinelli et } \\
\text { al. (2002 \& 2007) }\end{array}$ & $\sqrt{ }$ & & $\sqrt{ }$ & $\sqrt{ }$ & $\sqrt{ }$ & $\sqrt{ }$ & $\sqrt{ }$ & & & $\sqrt{ }$ & $\sqrt{ }$ & $\sqrt{ }$ & & $\sqrt{ }$ & $\sqrt{ }$ & & & & $\sqrt{ }$ & $\sqrt{ }$ & $\sqrt{ }$ & \\
\hline $\begin{array}{l}\text { Project Management Institute } \\
\text { (PMI) (2006) }\end{array}$ & & & & $\sqrt{ }$ & $\checkmark$ & & & & $\sqrt{ }$ & $\sqrt{ }$ & $\sqrt{ }$ & $\sqrt{ }$ & $\checkmark$ & $\sqrt{ }$ & $\sqrt{ }$ & & $\sqrt{ }$ & & & $\sqrt{ }$ & $\sqrt{ }$ & \\
\hline Rasdorf et al. (2010) & & $\sqrt{ }$ & $\sqrt{ }$ & & & & & & & & & & & & & & & & & & & \\
\hline Reiss et al. (2006) & $\sqrt{ }$ & $\sqrt{ }$ & & $\sqrt{ }$ & $\sqrt{ }$ & & $\sqrt{1}$ & & & $\sqrt{ }$ & $\sqrt{ }$ & $\sqrt{ }$ & & $\sqrt{ }$ & $\sqrt{ }$ & $\sqrt{ }$ & & & & $\sqrt{ }$ & & \\
\hline Remer \& Martin (2009) & & & $\sqrt{ }$ & & & & & & & & & & & & & & & & & & & \\
\hline Schexnayder et al. (2004) & & & & & & & & & & & & $\sqrt{ }$ & & & & & & & & & & \\
\hline $\begin{array}{l}\text { Shehu \& Akintoye (2009 \& } \\
2010)\end{array}$ & & & $\sqrt{ }$ & & $\sqrt{ }$ & & $\sqrt{ }$ & $\sqrt{ }$ & $\checkmark$ & $\sqrt{ }$ & & $\sqrt{ }$ & & $\checkmark$ & & & & & & $\sqrt{ }$ & $\sqrt{ }$ & \\
\hline $\begin{array}{l}\text { Thirty/ Thiry \& Deguire } \\
(2002 \& 2007)\end{array}$ & & & & & $\sqrt{ }$ & & & & & & & & & & & $\sqrt{ }$ & & & & & & \\
\hline Tang et al. (2008) & & & & & & & & & & & & & & & & & & & & & & $\sqrt{ }$ \\
\hline Wellman (2007) & & & $\sqrt{ }$ & & & $\sqrt{ }$ & & & & & & & & & & & & & & $\sqrt{ }$ & & \\
\hline Total & 4 & 3 & 10 & 11 & 14 & 6 & 5 & 3 & 2 & 9 & 8 & 9 & 3 & 8 & 5 & 5 & 5 & 4 & 4 & 9 & 5 & 2 \\
\hline
\end{tabular}

Table 2 Background of the five interviewees

\begin{tabular}{lllcc}
\hline No. & Positions & \multicolumn{1}{c}{ Divisions } & Year of industry experience & Number of megaprojects involved \\
\hline A & Head & Programme management office & 20 & 4 \\
B & Associate head & Programme management office & 12 & 3 \\
C & Associate head & Programme management office & 10 & 2 \\
D & Associate head & Programme management office & 10 & 2 \\
E & Deputy head & Cost management division & 12 & 2 \\
\hline
\end{tabular}




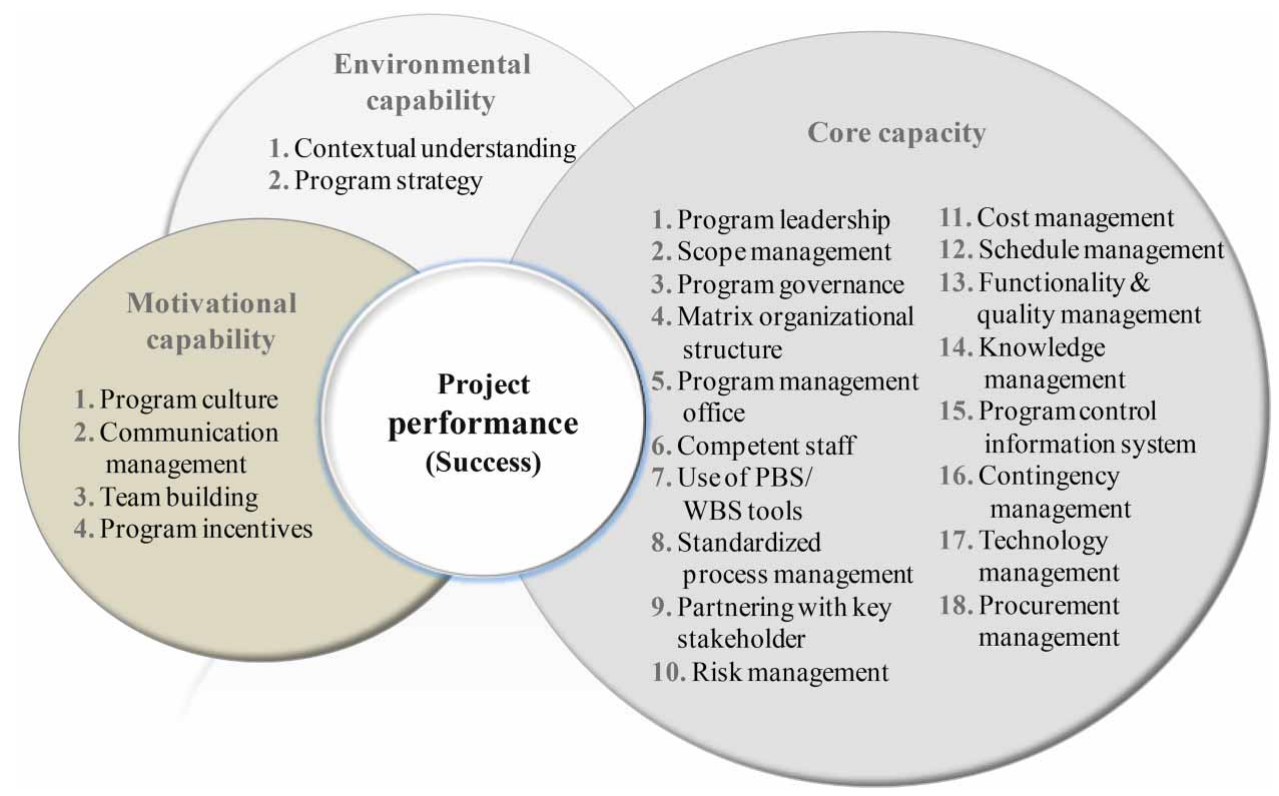

Figure 2 A framework of programme organizational capability for the success of construction megaprojects (updated)

programme organization established by its client for the construction megaproject should develop environmental capability, core capacity and motivational capability in these three aspects. Thus, a three-dimensional categorization framework of the $24 \mathrm{POF}$ has been established by refining the framework of IDRC and IADB (2002) in terms of organizational capability theory, as shown in Figure 2. The 24 POFs include two environmental factors, 16 capability factors and 4 motivational factors, which represent 3 capabilities of a programme organization established by its client to realize the success of construction megaprojects.

\section{Contextual capability}

Organizational environment is defined as 'a key factor in determining the level of available resources and the ease with which an organization can carry out its activities' (IDRC and IADB, 2002). In the case study, two POFs were identified relevant to this capability of the client programme organization.

Contextual understanding refers to the understanding of the environment within which a programme organization operates (Gray, 2001; Reiss et al., 2006). Most megaprojects today operate in an environment with high uncertainty, such as widespread economic fluctuation, population growth and increasing pressure from environmental and resource limitations (Shehu and Akintoye, 2010). A growing number of researchers have recognized the significance of contextual understanding in programme management (Partington et al., 2005; Pellegrinelli et al., 2007). China is a transitional economy; thus, the management of construction megaprojects encounters serious challenges not only from the fast-changing economic environment but also from the political and social aspects, such as migrant worker management, a fast construction mode required by the client and the increased demand for public engagement. Therefore, the client's understanding on environmental limits is essential in addressing the contextual challenges and sustaining megaproject success. In the case study, the client organized several rounds of internal discussions to analyse the contextual limits of project execution and employed an external programme management consultant to assist in addressing these contextual challenges in the design of the client's programme organization (SECH Office, 2008).

Programme strategy refers to the direction of a programme that makes the survival of the programme in its environment and contributes to success (Artto et al., 2008b). Office of Government Commerce (OGC, 2003) stated that the management of a programme has to deliver the strategic benefits, thus establishing a strategy is indispensable for programme organization to realize these benefits. Rasdorf et al. (2010) observed that an increasing trend of clients employing external programme managers (consultants) in the construction industry. Thus, integrated programme organizations with strong capability can be established to manage construction megaprojects. Similarly, the Shanghai Expo construction client established by the government temporarily constructed a client-led integrated programme organization by employing an 
external consultant to improve organizational capabilities and achieve the prescribed objectives (BSEC \& SCURCT, 2010).

\section{Core capacity}

Organizational core capacity can be defined the client's resource-based capability to execute a megaproject and sustain its effectiveness towards prescribed objectives (IDRC and IADB, 2002).In the case study, 16 POFs were identified relevant to this capability of the client programme organization.

Programme leadership is defined as 'the good leadership and clear direction setting at all levels within a program organization' (Reiss et al., 2006). Many scholars affirmed the significant role of leadership in constructing high-performing programme organizations (Pellegrinelli et al., 2007; Remer and Martin, 2009; Shehu and Akintoye, 2010; Dvir and Shenhar, 2011). In the case study, most leaders in the client organization, including programme directors, FMD heads and PMT heads, were strictly selected either from the government or from state-owned construction designers, contractors and consultants. They all had hands-on experience in managing construction megaprojects prior to receiving the appointments in the client organization; thus, they were considered qualified to form a strong executive level within the client organization and to contribute to improved efficiency in megaproject management.

Scope management refers to the identification, measurement and achievement of the expected benefits that a programme organization is intended to deliver (PMI, 2006). Lycett et al. (2004) stated that a programme exists to create value by improving the management of project isolation. Partington et al. (2005) advocated that scope management is essential in programme management. Timely adjustments in programme scope are also inevitable because the priorities of megaproject objectives change during the execution process (Ruuska et al., 2009). In the case study, the client organized several rounds of internal discussions and external consultations to identify the expectations of key stakeholders in formulating megaproject objectives, developing performance measures and executing the process accordingly (SECH Office, 2008, 2009).

Programme governance refers to a decision board that can sustain external resource input and ensure progress in accordance with the requirements of prescribed objectives (Nguyen et al., 2004; Reiss et al., 2006). Buuren et al. (2010) stressed four merits of a programme governance board in coordinating external stakeholders and improving work efficiency, namely interdepartmental integration within the government, multi-level governance integration, improving coherence between projects and hastening decision-making. Shehu and Akintoye (2010) also stated that a programme governance board has a key function in sustaining ample resources for programme execution. In the case study, the client established a governance board with the support of the Shanghai municipal government (SECH Office, 2008). The board was chaired by the Deputy Mayor and consisted of almost all senior officers from relevant governmental agencies and megaproject managers. The board facilitated project execution and coordinated the relationships with key external stakeholders.

Matrix organizational structure is an organizational form in which staff should report to departmental head and project leaders respectively. This factor is one of the characteristics of programme organizations (OGC, 2003). The matrix organizational structure includes the roles and responsibilities of the programme organization as well as their clear-cut relationships with the project breakdown structure (PBS)/work breakdown structure (WBS) outputs and the major benefits of the stakeholders (Reiss et al., 2006). Lycett et al. (2004) pointed out that proper attention should be given to programme roles and responsibilities in designing programme organizations for construction megaprojects. In the case study, the client established a matrix structure in designing the programme organization with 10 FMDs and 10 PMTs involved in PBS/ WBS output and project-type requirements (SECH Office, 2008). The strategy of decentralizing control to on-site PMTs was adopted to improve the autonomy of each PMT and facilitate timely frontline decisions on site (BSEC and SCURCT, 2010).

PMO is a collection of functions that serve for the programme decision level (Reiss et al., 2006). A PMO of programme organization coordinates the relationships between projects and cross-functional tasks (Artto et al., 2008a; Shehu and Akintoye, 2010) as well as handles the information needed for decisionmaking (Reiss et al., 2006). In the case study, the PMO operated by the consultant performed the two duties mentioned. The PMO also sustained the operation of the programme control information system (Le, 2009).

Competent staff refers to the qualified persons served in programme organizations. Shehu and Akintoye (2010) stated that the lack of qualified staff is a major obstacle in constructing high-performing programme organizations. Geraldi et al. (2010) agreed with his opinion, adding that competent staff is indispensable for the competitiveness of programme organizations. In the case study, the majority of staff serve in the programme organization were from local governmental agencies, designers, contractors and consultants 
through strict selection; they all had hands-on experience in the management of construction megaprojects.

PBS/WBS tools are managerial tools that enable the necessary communication between the clear understanding and statement of technical objectives at the programme level and the results of the work to be performed (PMI, 2006). These tools are often underestimated in programme management. Son et al. (2010) stated that using PBS/WBS tools is an indispensable procedure in applying a central programme control information system (PCIS) for managing construction megaprojects. In the case study, the consultant assisted the client in using PBS/WBS tools to align the tasks of different organizational units and the overall objectives of the megaproject. The use of PBS/WBS tools not only streamlined the relationships between the megaproject objectives and the organizational units, but also served as a basis to utilize a PCIS (SECH Office, 2008).

Standardized process management refers to the design and implementation of a standard process for all project management tasks to improve managerial efficiency and ensure continuous improvement. The process serves as the core of programme organization (Reiss et al., 2006; Shehu and Akintoye, 2009; Crawford and Nahmias, 2010). Maylor et al. (2006) stressed that process issues play an even more important role in programme management than that in project management. In the case study, the standard process includes 9 groups and 43 procedures and involved all management works performed by the client; relevant requirements were specified in the Guidelines of Shanghai Expo Construction Management and 9 Professional Engineering Management Handbooks (SECH Office, 2008, 2009).

Partnership with key stakeholders refers to the establishment of a strong relationship with key stakeholders involved in a programme (Chan et al., 2008). These stakeholders include designers, contractors and suppliers involved in a construction megaproject. Numerous studies have revealed that internal stakeholder management is crucial in sustaining programme success (Reiss et al., 2006; Pellegrinelli et al., 2007; Crawford and Nahmias, 2010). Davies et al. (2009) enumerated the benefits of managing megaprojects by partnership with major contractors. In the case study, the client organization established a close partnership with major designers and contractors by adopting multiple measures, such as using performance incentives in construction contracts and directly employing senior technical consultants from major contractor and design companies (SECH Office, 2008).

Risk management and insurance refers to tasks of keeping a programme's risk exposure at an acceptable level through proper insurance arrangements
(Pellegrinelli, 2002). Lycett et al. (2004) stated that risk management at the programme level is more important than that at the project level, which could address the strategic requirement. A US transportation agency attempted to introduce client insurance programme in managing megaproject risks (Schexnayder et al., 2004). This method can serve as an alternative strategy to address practical needs in some cases (Partington et al., 2005). In addition to the adoption of the construction risk insurance programme for all contractors (including building engineering, installation engineering and third party liability) that were compulsory requirements in local construction laws and regulation, the Shanghai Expo construction client also introduced an insurance programme for overall risks and comprehensive liability of all construction works within the Expo site; the insurance programme for consultants was also used in a number of constituent projects according to project need.

Cost management, the first of the 'iron triangle' objectives, refers to tasks that control programme expenditure in the approved budget. Programme organizations typically face a strict financial constraint by investors (Shehu and Akintoye, 2010). In the case study, a separate cost management division was established by the client in the programme organization to deal with all bidding, contracts, payments and auditing works. Through these tasks conducted by this FMD, the overall cost objective of the case could be centrally controlled by the client.

Schedule management, the second of the 'iron triangle' objectives, refers to activities of ensuring that the programme will produce its required deliverables and solutions on time (PMI, 2006).Thus, completing this objective is one of the core management activities of programme organizations. Partington et al. (2005) further emphasized the strategic significance of this task in all tasks of programme organization. In the case study, the client also established a separate time management division to manage the progress of the entire megaproject so that the overall progress of the case could be monitored and controlled.

Functionality and quality management, the third of the 'iron triangle' objectives, refers to activities that determine and ensure function and quality requirements to meet the prescribe objectives during execution (Reiss et al., 2006). Functionality and quality management is vital for construction of a megaproject to deliver a long-term operation facility or an infrastructure. In the case study, the client also established a safety and quality management division to gain a centralized control of all on-site safety and quality management works.

PCIS refers to an information management system that can collect, process and analyse all the sub-project 
information regularly and report programme progress regularly to decision-makers at the programme level. Many researchers affirmed the necessity of establishing a management system for controlling all objective measures at the programme level (Pellegrinelli et al., 2007; Shehu and Akintoye, 2009). PCIS can also be used as a communication platform facilitating collaborative works among designers, contractors, the client and other stakeholders (Davies et al., 2009). For instance, South Korea has also been developing its own PCIS to manage urban renewal megaprojects in order to improve management efficiency and achieve better performance (Kim et al., 2009). In the case study, the Chinese client adopted two softwares, the construction contract and cost administration (C3A) information system and Primavera $3 E / C$, to deal with different information needs. The former was used to deal with contract and cost information and output as monthly cost control report; the latter was used to identify the milestones of the overall programme and control programme progress. The two softwares were operated by the cost management division and the time management division through external consultants, respectively.

Knowledge management refers to tasks that capture and share knowledge through monitoring and review to improve a programme's likelihood of success (Reiss et al., 2006). Shehu and Akintoye (2010) stated that construction programmes can benefit significantly from sharing some resources of projects that will help to improve the accuracy and efficiency of executing the projects within a programme. Lycett et al. (2004) analysed the levels of knowledge transfer in programme management and emphasized that more effective knowledge transfer can be obtained by identifying and improving upon transferable lessons at two levels with a programme. Beehler (2009) stated that clients could obtain relevant experience by employing an external programme management consultant. In the case study, the client employed a programme management consultant and several project management consultants (for PMTs) to improve knowledge obtaining and sharing at the programme level and at the constituent project level; communications for knowledge transfer between the two levels were also encouraged by the client. The programme consultant also assisted the client in establishing a unified archival and information management system to record and organize all construction documents of the client.

Contingency management refers to a capability of programme organization to address any accident or unexpected event or disaster. Unexpected events are common in megaprojects, such as the London Heathrow Terminal 5 construction and Hong Kong International Airport construction (Davies et al., 2009; Brady and Davies, 2010). This is because the extremely large size of these projects challenges the experience in the management of similar projects. Geraldi et al. (2010) provided a three-pillar framework for programme contingency management: (1) responsive and functioning structure at the organizational level, (2) good interpersonal relationship at the group level and (3) competent staff at the individual level. In the case study, two contingency management networks, emergency management and flood control, were established by the client to deal with different emergencies. The former referred to a standing network that includes the client's Emergency Management Commission and branches set up by all on-site project/sub-programme management teams and key contractors; the latter referred to a temporary network mainly in response to any emergency that might be caused by flood, typhoon and other extreme weather in the summer, which also the client's Flood Control Commission and branches set up by all on-site project/sub-programme management teams and key contractors. Within these networks, various processes and plans for emergency responses were developed and reviewed annually; meeting and drills were also held regularly to deal with emergency response needs.

Technology management refers to tasks related to design and technical issues in construction megaprojects. Construction megaprojects today may face an increased technical complexity as a result of the rapid development of new materials and technologies. Increased use of these materials and technologies in practice, such as virtual construction technology, energy conservation technologies and new construction materials, is inevitable in the construction industry (Harty et al., 2007). Thus, design and technology management is a crucial and highly influential factor for clients in construction programme organizations and sustaining relevant objectives. Archival documents indicated that the Shanghai Expo construction adopted hundreds of energy conservation and green construction technologies in its design and construction process to meet the objective of 'Green Expo, Lowcarbon Expo' (UNEP, 2009); thus, the client set up a design management division to coordinate all design and technology management activities (SECH Office, 2008).

Procurement management refers to tasks that procure the necessary equipment and materials. This factor is an often-overlooked but indispensable aspect for client in constructing programme organizations for construction megaprojects (PMI, 2006). In the case study, the client set up a procurement management division to manage and complete over 150 project contracts with nearly 10 suppliers in collaboration with the cost management division, including bidding, logistics arrangements, onsite support and contract payments. 


\section{Motivational capability}

Organizational motivational capability reflects the client's underlying capability to drive its members within the organization and key participants outside the organization to maintain the effectiveness of megaproject execution (IDRC and IADB, 2002). In the case study, four POFs were identified relevant to this capability of the client programme organization.

Organizational culture manifests itself in the formal and informal rules of a programme organization (IADB and IDRC, 2002). Programme organizations established to manage construction megaprojects are temporary; a common culture should be established to improve coherence within a programme organization and achieve its mission. Pellegrinelli (2002) emphasized that programme culture is crucial in improving the capability of programme organization. To promote a positive competitive culture among all key participants involved in the Shanghai Expo case, including designers, consultants, contractors and the client's FMDs and PMTs, the construction competition activities were conducted regularly by an HR management division of the client organization. In each year of the entire construction period, outstanding individuals and teams within the client organization or from the key participants that excelled in internal competitions were recommended by the client to participate in annual labour competitions initiated by local and national labour unions; some of these individuals and teams also received the 'May 1st' Labor Medals and 'May 1st' Labor Awards respectively, which were the highest national awards for individuals and teams. Therefore, a positive competitive culture was established by conducting these activities.

Communication management refers to communications activities within a programme organization and across organizational boundaries. Shehu and Akintoye (2010) stated that the lack of cross-functional communication is a major obstacle in establishing an effective programme organization, while timely and effective communication between project teams or across organizational boundaries could contribute significantly to programme success (Nguyen et al., 2004). Reiss et al. (2006) emphasized that internal communication should be considered as a separate task in a programme organization. In the case study, the client established several measures to promote internal communication among the FMTs and PMTs and external communication among designers, contractors, suppliers and government agencies. The forms of communication employed include regular and informal meetings, newsletters, training programmes and joint work activities (e.g. joint site inspection and emergency drills).
Team building aims to develop individual and team capabilities to enhance programme performance (PMI, 2006). Kumaraswamy et al. (2005) emphasized that team work is essential in sustaining the performance of construction megaprojects and that team building is necessary to achieve effective team work. Although most programme organizations are temporary, coherence with a programme organization must be improved by adopting several measures (Ko and Paek, 2008). Shehu and Akintoye (2010) proposed a staff training programme as an effective method to improve team building. In the case study, the entire client organization includes approximately 400 persons from different government agencies, contractors, designers and consultants. Although the diversified composition of the client organization could constitute a strong management (Pellegrinelli, 2002), it also represented a great challenge for the client in team management. Thus, strengthening team building of the entire client organization was a core work of the client's HR management division. This FMD adopted multiple measures to boost team building in the client organization: (1) regular training courses and seminars, (2) annual meetings and (3) regular cross-functional communication activities. These activities considerably improved the unity and coherence of client staff, thus consequently enhanced the efficiency of the programme organization.

Programme incentives are commonly used to reduce overall contract cost, control time and increase the support of specific performance objectives, such as productivity, quality, safety, technological progress, innovation and management. They have been widely used in the construction industry to improve the performance of construction projects. European Construction Institute (2003) stated that contract incentives could be employed to strengthen the partnership between the client and key stakeholders, such as contractors, and therefore sustain programme performance. In the case study, contract and other incentives were used as a combination by the client to improve the overall performance of the megaproject in time, safety, quality and environment.

\section{Characteristics of the programme organization capability model}

Compared with mainstream organizational models with 10 factors or less involved, the programme organization model consisting of 24 POFs proposed in this study represents almost all key issues of a programme organization in managing megaprojects and provide an more overall picture of building and operating a programme organization in practice. These POFs are grouped 
under three categories, namely contextual capability, core capacity and motivational capability. The following are the characteristics of the conceptual model.

(1) The first category refers to the capability of a programme organization to understand and response to project context and its potential changes. Programme organizations established to conduct long-term undertakings today operate in a changing environment; thus, contextual understanding and strategic management are crucial to construct and sustain an effectiveness programme organization. The two POFs are contextual elements in programme organizations because they represent the environmental capability.

(2) The 18 POFs refer to the hard side of a programme organization in managing its megaproject, which are the normative and technical elements of a programme organization to construct its core capacity. These POFs can represent the coordination and integration capabilities of programme organizations to control dispensed executions (OGC, 2003; PMI, 2006; Davies et al., 2009). These POFs should take both coordination and integration roles in practice, such as PMO, cost management, and functionality and quality management.

(3) The last category consisting of the four POFs refers to the soft side of a programme organization used to sustain its dynamics in the megaproject delivery process (organizational life cycle). Compared with project organizations, programme organizations often have a life cycle of five years or even longer, thus, developing motivational capability has become indispensable for clients in maintaining the effectiveness of programme organizations. In the case study, the client's programme organization developed its motivational capability mainly through the four cultural-cognitive POFs. These findings reinforced the statement of Chan (1994) that the significance of motivation activities within a project had a positive relationship with the project size.

\section{Limitations of this study}

Identifying critical factors and formulating a pragmatic framework are significant challenges as a result of the potential gap between the journal literature and practical knowledge and experience; thus, this study has just proposed a pragmatic 24-POF framework of programme organization capability for delivering megaprojects from the client perspective. As the first phase of a phased research study, further study will look at developing a more comprehensive critical success factor list and investigating relationships between the newly identified factors and megaproject performance. In addition, there exist three specific limitations in this model developed in this study.

(1) Compared with classic project management frameworks with 10 or less factors involved (e.g. PMI's 9-aspect knowledge body of project management), the seemingly large number of the POFs proposed in this study might cause potential overlaps in the scopes of some POFs, but it could provide a more thorough and pragmatic understanding of all key issues of programme organizations in megaprojects, which may serve as a good foundation for future study (Hu et al., 2013).

(2) The development of the framework in this study is also limited to the literature review within the study period of 2000-2010. With the recognition that there exists a rapid development in the project and programme management field (Morris, 2013) and the developed theoretical model mainly derived from the literatures published in this period might have not addressed the latest developments in this field, although some megaproject-related papers from the same sources are used to complement the theoretical foundation, the theoretical foundation in this study still has room for improvement. Search for the relevant literature should be continued to refine the theoretical foundation.

(3) Another limitation of this study lies in the small sample size of a single case study. Construction megaprojects may have different types, characteristics and requirements; thus, the programme organization framework developed in this study may require further refinements to adjust for other types of megaprojects.

\section{Conclusions and recommendations for future research}

The Economist (2008) predicted that the number of infrastructure and urban construction megaprojects would continue to grow not only in China, but in other parts of the world as well. Programme management has been increasingly advocated as a pragmatic approach for improving the megaproject performance at the overall organizational level (Beehler, 2009; Pellegrinelli et al., 2011). While most discussions consider 
the concept for construction programme management in general, little has been done on research on pragmatic models, such as client's organizations. Therefore, the establishment of this conceptual framework is believed to be a timely work for the clients and professionals involved in construction megaprojects.

This study is the first attempt to develop a pragmatic framework of programme organization for managing construction megaprojects in China. Although this framework has been developed based on a single case study, it has made mixed-style efforts through the literature review and case-based interviews so that a conceptual framework of programme organizational capability with 24 POFs included was proposed. Through the establishment of this conceptual model, the knowledge of both researchers and industry professional about utilizing programme management approach managing megaprojects can be enriched. On the one hand, it has provided an overall picture of the operation of a programme organization in megaproject practice, not only enhancing previous studies on programme management in construction, but also paving the way for further on the organization factors in construction megaprojects. On the other hand, clients and professionals can learn about the factors for setting up an effective organization and sustain its effectiveness to accomplish the prescribed megaproject objectives. Considering that the findings of this study have been derived from single case study in China, more empirical efforts should be devoted to other megaprojects, such as highspeed railways, dams and major theme parks. Different principal POFs and their influence on the success of different megaprojects may be further investigated. With sufficient empirical findings generated from different megaprojects and from different countries, a Megaproject Management Body of Knowledge may be established for wider practical application.

\section{Acknowledgement}

This work is a development of the 2012 EPOS conference paper, entitled 'Conceptual framework of program organization for managing construction megaprojects-Chinese client's perspective'. Special gratitude also goes to the Associate Editor and three anonymous reviewers for their insightful comments and suggestions on earlier versions of this manuscript.

\section{Funding}

This work described in this paper has been funded by The Hong Kong Polytechnic University and the National Science Foundation of China [grant number 71390523] and received support from the Department of Construction Management and Real Estate, Tongji University and the Shanghai Expo Group Company.

\section{References}

Artto, K., Martinsuo, M., Gemuenden, H.G. and Murtoaro, J. (2008a) Foundations of program management: a bibliometric view. International fournal of Project Management, 27(1), 1-18.

Artto, K., Kujala, J., Dietrich, P. and Martinsuo, M. (2008b) What is project strategy? International fournal of Project Management, 26(1), 4-12.

Beehler, M. E. (2009) Lessons learned on mega projects, in Vogt, M.W. (ed.) Proceedings of Electrical Transmission and Substation Structures Conference 2009: Technology for the Next Generation, American Society of Civil Engineers, Fort Worth, TX, pp. 71-8.

Brady, T. and Davies, A. (2010) From hero to hubrisreconsidering the project management of Heathrow's Terminal 5. International fournal of Project Management, 28(2), 151-7.

Bureau of Shanghai Expo Coordination (BSEC) and Shanghai Commission of Urban and Rural Construction and Transportation (SCURCT). (2010) Shanghai Expo Engineering Construction [only the Chinese version], Shanghai Scientific and Technical Publishers, Shanghai.

Buuren, A.V., Buijs, J.M. and Teisman, G. (2010) Program management and the creative art of cooperation: dealing with potential tensions and synergies between spatial development projects. International fournal of Project Management, 28(7), 672-82.

Chan, A.P.C. (1994) Managerial responsibility of project managers. Australian Institute of Building Papers, 5(1993/ 1994), 109-20.

Chan, A.P.C., Chan, D.W.M., Fan, W.C.N.L., Lam, P.T.I. and Yeung, F.Y. (2008) Achieving partnering success through an incentive agreement: lessons learned from an underground railway extension project in Hong Kong. Fournal of Management in Engineering, 24(3), 128-37.

Crawford, L. and Nahmias, A.H. (2010) Competencies for managing change. International fournal of Project Management, 28(4), 405-12.

Davies, A., Gann, D. and Douglas, T. (2009) Innovation in megaprojects: system integration at London Heathrow Terminal 5. California Management Review, 51(2), 101-25.

Dosi, G., Nelson, R.R. and Winter, S.G. (2000) Introduction, in Dosi, G., Nelson, R.R. and Winter, S.G. (eds.) The Nature and Dynamics of Organizational Capabilities, Oxford University Press, Oxford, pp. 1-22.

Dvir, D. and Shenhar, A.J. (2011) What great projects have in common? MIT Sloan Management Review, 52(3), 18-21.

(The) Economist. (2008) Record spending on infrastructure will help to sustain rapid growth in emerging economies. The Economist, 387(8583), p. 88.

European Construction Institute (ECI) (2003) Long-term Partnering-Achieving Continuous Improvement and Value, European Construction Institute, London. 
Eweje, J., Turner, R. and Müller, R. (2012) Maximizing strategic value from megaprojects: the influence of information-feed on decision-making by the project manager. International fournal of Project Management, 30(6), 639-51.

Flyvbjerg, B., Bruzelius, N. and Rothengatter, W. (2003) Megaprojects and Risk: An Anatomy of Ambition, Cambridge University Press, Cambridge.

Geraldi, J.G., Lee-Kelley, L. and Kutsch, E. (2010) The Titanic sunk, so what? Project manager response to unexpected events. International fournal of Project Management, 28(6), 547-58.

Gray, R.J. (2001) Organizational climate and project success. International Fournal of Project Management, 19(2), 103-9.

Greiman, V. (2010) The big dig: Learning from a megaproject. Academy Sharing Knowledge Magazine, Issue 39, 47-52.

Haigh, R. (2008) Interviews: a negotiated partnership, in Knight, A. and Ruddock, L. (eds.) Advanced Research Methods in the Built Environment, Wiley-Blackwell, Chichester.

Harty, C., Goodier, C.I., Soetanto, R., Austin, S., Dainty, A. R.J. and Price, A.D.F. (2007) The futures of construction: a critical review of construction future studies. Construction Management and Economics, 25(5), 477-93.

$\mathrm{Hu}, \mathrm{Y}$., Chan, A.P.C. and Le, Y. (2013) From construction megaproject management to complex project management: a bibliographic analysis. Fournal of Management in Engineering.doi:10.1061/(ASCE)ME.1943-5479.0000254

International Development Research Center (IDRC) and Inter-American Development Bank (IADB). (2002) Organizational Assessment: A Framework for Improving Performance, International Development Research Centre, Ottawa, ON.

International Project Management Association (IPMA). (2006) ICB-IPMA Competency Baselines, Version 3.0. Available at IPMA website: http://www.ipma.ch/ downloads/Pages/Certification.aspx

International Project Management Association (IPMA). (2014) Success stories: China's 2010 IPMA Award Winner Receives Million Yuan Reward. Available at IPMA website: http://ipma.ch/awards/success-stories/ (accessed 9 July 2014).

Ke, Y.J., Wang, S.Q., Chan, A.P.C. and Cheung, E. (2009) Research trend of public-private-partnership (PPP) in construction journals. Fournal of Construction Engineering and Management,135(10), 1076-86.

Kim, J.H., Yoon, J.Y., Kim, K.H. and Kim, J.J. (2009) A Conceptual model of intelligent program management information systems (iPMIS) for urban renewal mega projects in Korea. Fournal of Asian Architecture and Building Engineering, 8(1), 57-64.

King, A. (2008) Using software to analyze qualitative data, in Knight, A. and Ruddock, L. (eds.) Advanced Research Methods in the Built Environment, John Wiley and Sons, Chichester, pp. 135-143.

Ko, O.Y. and Paek, J.H. (2008) Korea experience project management consortium on the US forces Korea relocation program. Fournal of Asian Architecture and Building Engineering, 7(1), 85-92.
Kumar, S. and Hsiao, J.K. (2007) Engineers learn 'soft skills the hard way': planting a seed of leadership in engineering classes. Leadership and Management in Engineering, 7(1), 18-23.

Kumaraswamy, M., Ling, F., Rahman, M. and Phng, S. (2005) Constructing relationally integrated team. Fournal of Construction Engineering and Management, 131(10), 1076-86.

Le, Y. (2009) Five Key Techniques for Large and Complex Construction Project [only the Chinese version], A Research Report for Shanghai Scientific and Technology Committee, Tongji University, Shanghai.

Lehtonen, P. and Martinsuo, M. (2008) Change program initiation: defining and managing the program-organization boundary. International fournal of Project Management, 26 (1), 21-29.

Lycett, M., Rassau, A. and Danson, J. (2004) Programme management: a critical review. International fournal of Project Management, 22(4), 289-99.

Maylor, H., Brady, T., Cooke-Davies, T. and Hodgson, D. (2006) From projectification to programmification. International fournal of Project Management, 24(8), 663-74.

Modig, N. (2007) A continuum of organizations formed to carry out projects: temporary and stationary organization forms. International fournal of Project Management, 25(8), 807-14.

Molenaar, K.R. (2005) Programmatic cost risk analysis for highway megaprojects. Fournal of Construction Engineering and Management, 131(3), 343-53.

Morris, P.W.G. (2011) A brief history of project management, in Morris, P.W.G., Pinto, J.K. and Söderlund, J. (eds.), The Oxford Handbook of Project Management, Oxford University Press, Oxford, pp. 15-36.

Morris, P.W.G. (2013) Reconstructing Project Management, John Wiley \& Sons, London.

Morris, P.W.G. and Hough, G.H. (1987) The Anatomy of Major Projects: A Study of the Reality of Project Management, John Wiley \& Sons, Chichester.

Nguyen, L.D., Ogunlana, S.O. and Lan, D.T.X. (2004) A study on project success factors in large construction projects in Vietnam. Engineering, Construction and Architectural Management, 11(6), 404-13.

Nieminen, A. and Lehtonen, M. (2008) Organizational control in programme teams: an empirical study in change programme context. International fournal of Project Management, 26(1), 63-72.

Office of Government Commerce (OGC). (2003) Managing Successful Programmes: Delivering Business Change in Multi-projects Environments, The Stationary Office, London.

O'Leary, T. and Williams, T. (2008) Making a difference? Evaluating an innovative approach to the project management Centre of Excellence in a UK government department. International fournal of Project Management, 26(5), 556-65.

Partington, D., Pellegrinelli, S. and Young, M. (2005) Attributes and levels of programme management competence: an interpretive study. International fournal of Project Management, 23(2), 87-95. 
Pellegrinelli, S. (2002) Shaping context: the role and challenge for programmes. International fournal of Project Management, 20(3), 229-33.

Pellegrinelli, S., Partington, D., Hemingway, C., Mohdzain, Z. and Shah, M. (2007) The importance of context in programme management: an empirical review of programme practices. International fournal of Project Management, 25 (1), 41-55.

Pellegrinelli, S., Partington, D. and Geraldi, J.G. (2011) The Oxford Handbook of Project Management, edited by Morris P.W.G., Pinto, J.K. and Soderlund, J, Oxford University Press, Oxford, pp.252-272.

Project Management Institute (PMI). (2006) The Standard for Program Management, Project Management Institute, Newtown Square, PA.

Rasdorf, W., Grasso, B. and Bridgers, M. (2010) Public versus private perceptions on hiring an external program manager. Fournal of Construction Engineering and Management, 136(2), 219-26.

Reiss, G., Anthony, M., Chapman, J., Leigh, G.Pyne, A. and Rayner, P. (2006) Gower Handbook of Programme Management, Gower, Aldershot.

Remer, D.S. and Martin, M.A. (2009) Project and engineering management certification. Leadership and Management in Engineering, 9(4), 177-90.

Remington, K. and Pollack, J. (2008) Tools for Complex Projects, Gower, Hampshire.

Ruuska, I., Artto, K., Aaltonen, K. and Lehtonen, P. (2009) Dimensions of distance in a project network: exploring Olkiluoto 3 nuclear power plant project. International Fournal of Project Management, 27(2), 142-53.

Schexnayder, C.J., Weber, S.L. and David, S.A. (2004) Transportation agency use of owner-controlled insurance programs. Fournal of Construction Engineering and Management, 130(4), 517-24.

Shanghai Expo Construction Headquarters (SECH) Office. (2008) The outlines of Shanghai Expo Construction, Unpublished internal document, SECH Office, Shanghai.

Shanghai Expo Construction Headquarters (SECH) Office. (2009) The outlines of Shanghai Expo Construction, Unpublished internal document, SECH Office, Shanghai.
Shehu, Z. and Akintoye, A. (2009) Construction programme management theory and practice: contextual and pragmatic approach. International fournal of Project Management, 27 (7), 703-16.

Shehu, Z. and Akintoye, A. (2010) Major challenges to the successful implementation and practice of programme management in the construction environment: a critical analysis. International fournal of Project Management, 28, 26-39.

Son, M.J., Kim, S.R., Jin, R.Z., Cho, K.M. and Hyun, C.T. (2010) Development of the intelligent program management information system (I-Pgmis) framework for megaprojects, in J. G. Teng (ed.) Proceedings of the First International Conference on Sustainable Urbanization, The Hong Kong Polytechnic University, Hong Kong.

Tang, W.Z., Qiang, M.S., Duffield, C.F., Young, M.D. and Lu, Y.M. (2008) Incentives in Chinese construction industry. Fournal of Construction Engineering and Management, 134 (7), 457-67.

Thiry, M. (2002) Combining value and project management into an effective programme management model. International fournal of Project Management, 20(3), 22127.

Thiry, M. and Deguire, M. (2007) Recent developments in project-based organizations. International fournal of Project Management, 25(7), 649-58.

United Nations Environmental Programmes (UNEP). (2009) The Environmental Impact Assessment Report of Expo 2010 Shanghai, China, available at http:/www.mep.gov.cn/pv obj_cache/pv_obj_id_31F5A773F5AA14C147650F6BCA 21652E5EBE6D00/filename/P020100421509153237050. pdf (assessed 2 November 2011).

Ventresca, M.J. and Mohr, J.W.(2005). Archival research methods, in Baum, J.A.C. (ed.) The Blackwell Companion to Organizations, Blackwell Publishing, Oxford, pp. 805-28.

Wellman, J. (2007) Leadership behaviors in matrix environments. Project Management fournal, 38(2), 62-74.

Xue, Y., Anbari, F.T. and Turner, J.R. (2008) Maximizing results from key infrastructure projects: the case of China, in Proceedings of 22th International Project Management Association World Congress, Roma, Italy. 